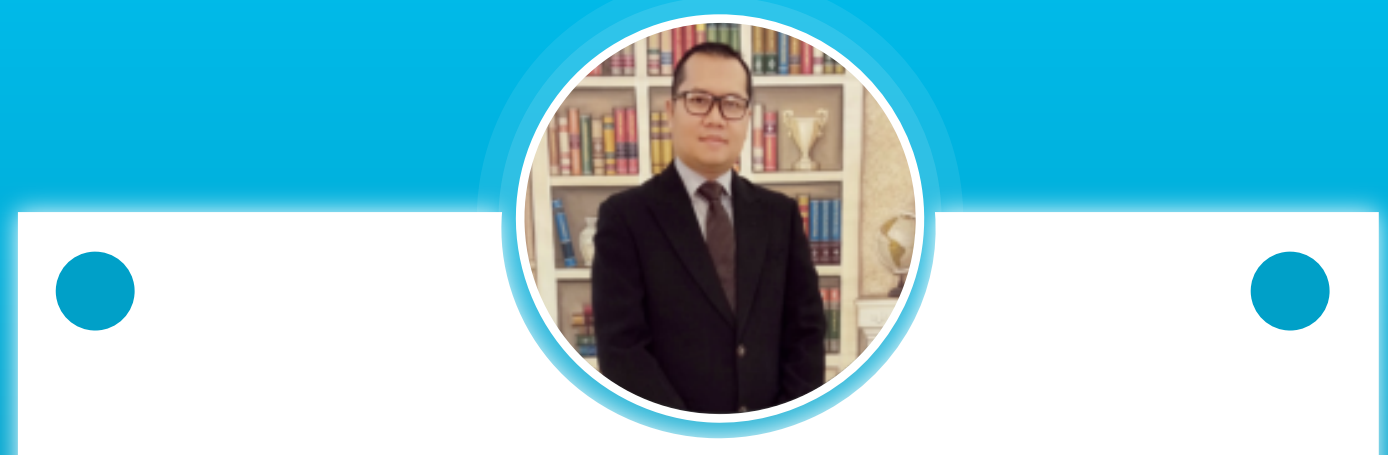

Ns. Sahrudi, S.Kep., M.Kep., Sp.Kep.MB

Buku ini dibuat berdasarkan hasil studi kasus pada pasien yang mengalami Neglected Fraktur Shaft Femur Sinistra Dengan Pendekatan Teori Virginia Henderson. Prinsip utama pemberian asuhan keperawatan dengan menggunakan model Virginia Henderson adalah membantu pasien untuk mencapai kemandirian terhadap masalah yang dialami. Model konsep Virginia Henrderson memiliki unsur yang sama dengan proses keperawatan dan mampu mewakili respon kebutuhan pasien terhadap penyakitnya. Tahapan dalam proses keperawatan menurut Virginia Henderson di awali dari pengkajian yang berdasarkan 14 kebutuhan dasar manusia. Setiap kebutuhan dikaji secara komprehensif meliputi data subjektif dan objektif, melakukan pemeriksaan fisik, mengobservasi pemeriksaan penunjang. Diagnosa keperawatan berdasarkan NANDA yang diangkat sesuai dengan masalah yang muncul dari 14 kebutuhan dasar manusia, etiologi didasarkan pada patofisiologi penyakit yang berhubungan dengan kondisi pasien. Intervensi merujuk pada kriteria $\mathrm{NIC}$, hasilnya merujuk para kriteria NOC. Pelaksanaan implementasi didasarkan pada pencapaian kriteria hasil dan evaluasi dilihat dari perkembangan pasien dalam mencapai kemandirian.
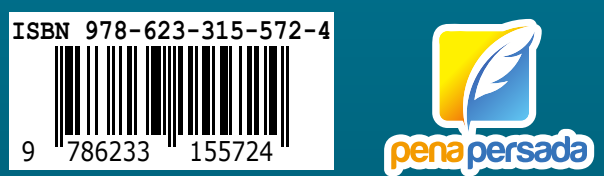

Aplikasi Asuhan Keperawatan

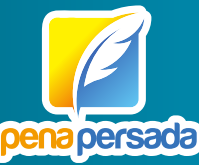

\section{NEGLECTED FRACTURE OF LEFT SHAFT FEMUR} dengan teori

\section{VIRGINIA HENDERSON}

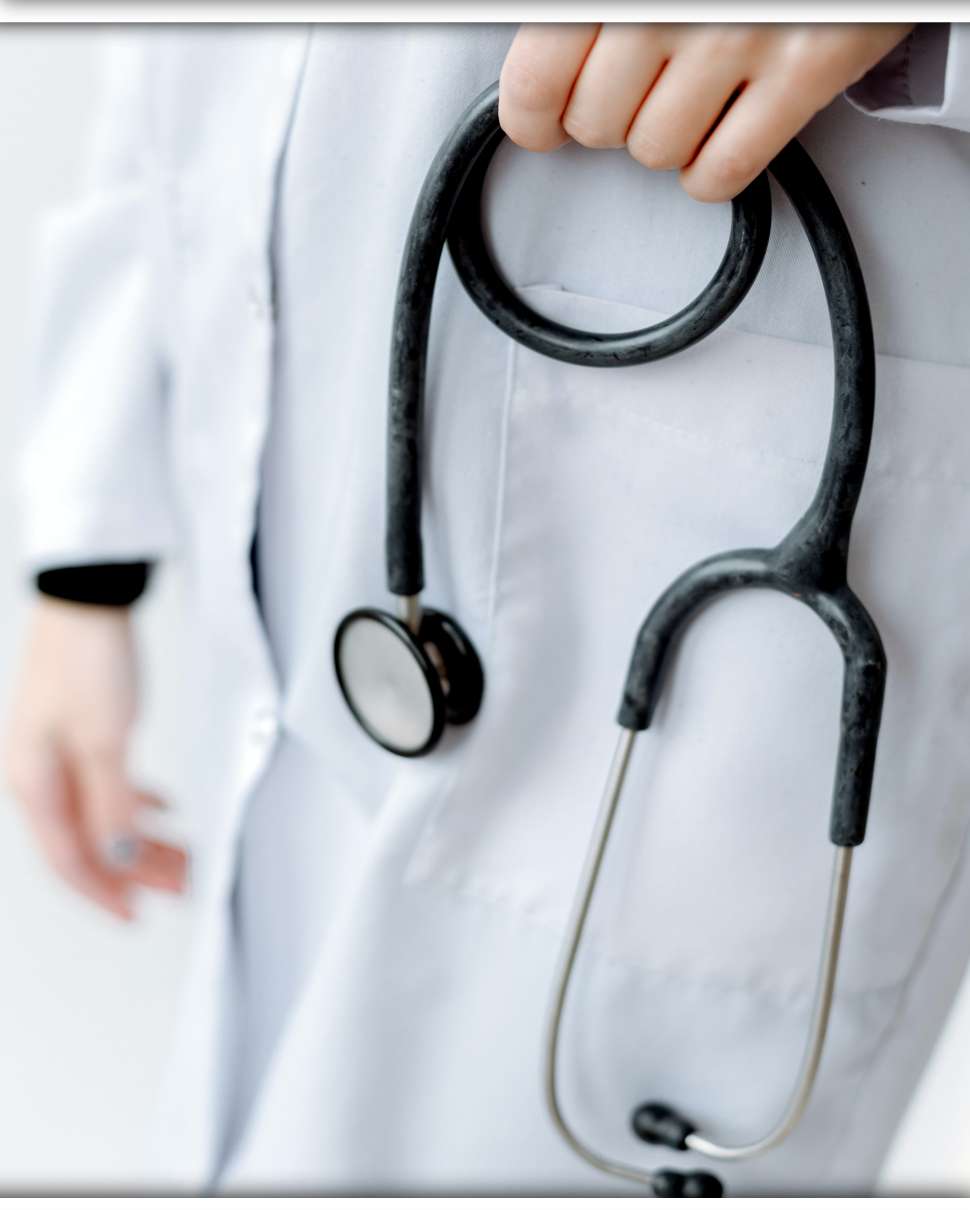

Ns. Sahrudi, S.Kep., M.Kep., Sp.Kep.MB 


\title{
Aplikasi Asuhan Keperawatan NEGLECTED FRACTURE OF LEFT SHAFT FEMUR dengan TEORI VIRGINIA HENDERSON
}

\author{
Ns. Sahrudi, S.Kep., M.Kep., Sp.Kep.MB
}

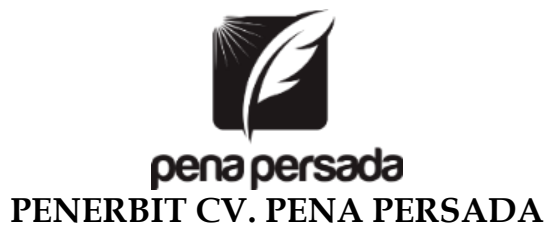




\title{
Aplikasi Asuhan Keperawatan NEGLECTED FRACTURE OF LEFT SHAFT FEMUR dengan TEORI VIRGINIA HENDERSON
}

\author{
Penulis: \\ Ns. Sahrudi, S.Kep., M.Kep., Sp.Kep.MB
}

ISBN: 978-623-315-572-4

Design Cover:

Retnani Nur Briliant

Layout:

Nisa Falahia

\section{Penerbit CV. Pena Persada \\ Redaksi:}

Jl. Gerilya No. 292 Purwokerto Selatan, Kab. Banyumas

Jawa Tengah

Email: penerbit.penapersada@gmail.com

Website: penapersada.com Phone: (0281) 7771388

\section{Anggota IKAPI}

All right reserved

Cetakan pertama: 2021

Hak Cipta dilindungi oleh undang-undang. Dilarang memperbanyak karya tulis ini dalam bentuk apapun tanpa izin penerbit dan penulis 


\section{KATA PENGANTAR}

Segala puji dan syukur kami panjatkan selalu kepada Allah SWT atas rahmat, taufiq, dan hidayah-Nya sehingga penulis dapat menyelesaikan buku yang berjudul "Aplikasi Asuhan Keperawatan NEGLECTED FRACTURE OF LEFT SHAFT FEMUR dengan TEORI VIRGINIA HENDERSON". Buku ini dibuat berdasarkan hasil studi kasus pada pasien yang mengalami Neglected Fracture dengan pendekatan teori keperawatan Virginia Henderson .

Buku ini dirancang sebagai sumber informasi tentang penerapan teori Virginia Henderson. Semoga buku ini dapat memberi kontribusi bagi perkembangan ilmu keperawatan di Indonesia.

Jakarta, Agustus 2021

Penulis 


\section{DAFTAR ISI}

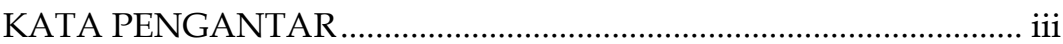

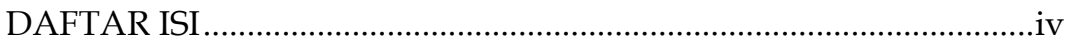

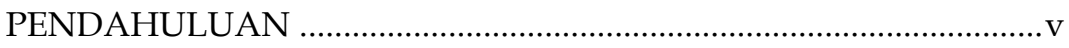

BAB I ANATOMI DAN FISIOLOGI TULANG ….................................. 1

A. Tulang .......................................................................... 1

B. Histologi Jaringan Tulang ..................................................... 2

C. Substansi Tulang Kompak ..................................................... 4

D. Substansi Tulang Spongiosa .................................................

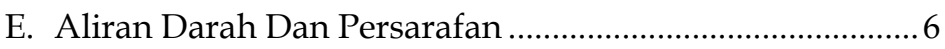

F. Klasifikasi Tulang …........................................................

BAB II KONSEP FRAKTUR SHAFT FEMUR DAN TEORI VIRGINIA HENDERSON ..................................................10

A. Fraktur Shaft Femur.........................................................10

B. Neglected Fracture .................................................................

C. Teori Virginia Henderson ..................................................18

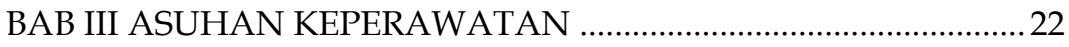

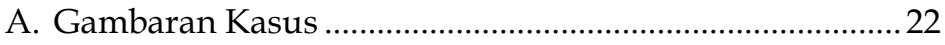

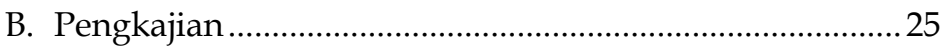

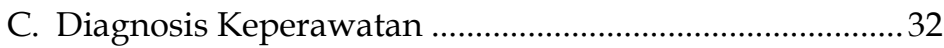

D. Tujuan dan Intervensi Keperawatan ....................................33

E. Implementasi dan Evaluasi .................................................52

BAB IV IMPLIKASI TEORI VIRGINIA HENDERSON .......................62

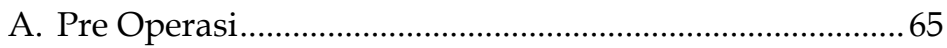

B. Post Operasi .................................................................... 70

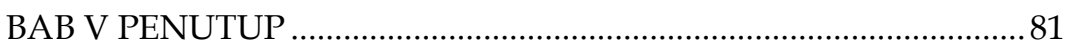

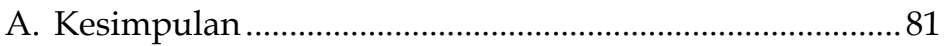

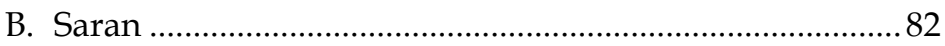

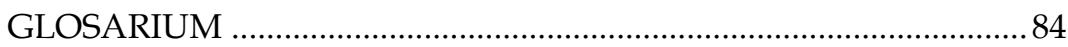

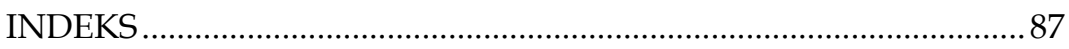

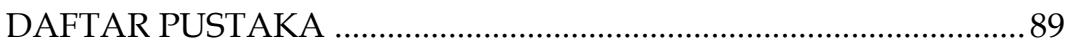

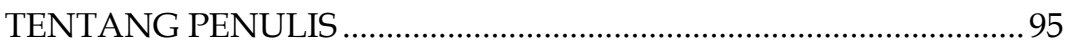




\section{PENDAHULUAN}

Fraktur merupakan kondisi hilangnya kontinuitas tulang yang dapat disebabkan oleh faktor trauma dan non trauma, adapun yang termasuk faktor trauma yaitu terjatuh atau cedera, sedangkan faktor non trauma seperti pada kasus osteoporosis (Blom, Warwick, \& Whitehouse, 2018). Dilaporkan bahwa satu dari empat orang Amerika mengalami gangguan muskuloskeletal dan sekitar 40\% gangguan muskuloskeletal ini penyebab ketidakmampuan fisik (Orthopedic Research Foundation, 2010). Di Indonesia yaitu di Rumah Sakit Umum Pusat Fatmawati sebagian besar gangguan muskuloskeletal disebabkan oleh fraktur. Di perkirakan sekitar $80 \%$ fraktur pada ektremitas bawah, $5 \%$ fraktur ektremitas atas, 5\% fraktur pelvis, 5\% fraktur pinggul, 5\% fraktur pada tulang belakang ( Rekam medis RSUP Fatmawati, 2018). Saat ini kecendrungan pasien dengan gangguan muskuloskeletal semakin bertambah banyak. Hal ini berkaitan dengan penggunaan jalan raya dan bertambahnya jumlah kendaraan bermotor menjadi faktor penyebab semakin bertambahnya angka kecelakaan lalu lintas yang menimbulkan cedera pada organ tubuh termasuk cedera pada tulang. Selain itu, faktor lainnya yang menyebabkan gangguan muskuloskeletal juga diakibatkan oleh penyakit degeneratif, kongenital dan onkologi/ keganasan (Rasjad,2012).

Komplikasi yang paling sering terjadi pada kasus fraktur adalah mal union, delay union, dan non union. Mal union merupakan kondisi penyambungan tulang yang tidak sesuai dengan tempatnya sehingga menimbulkan deformitas. Delay union yaitu kondisi keterlambatan penyambungan tulang, sedangkan non union adalah kondisi tidak terjadinya 
penyambungan tulang (Smeltzer \& Bare's, 2017). Penanganan fraktur yang tidak semestinya biasanya dilakukan oleh bone setter (pengobatan tradisional/dukun patah tulang) yang masih sering dijumpai di masyarakat Indonesia.

Menurut riset kesehatan dasar pada tahun 2013 pemanfaatan pengobatan tradisional di masyarakat sebesar 30,4 \%, baik itu pengobatan dengan ramuan, bantuan alat, atau pikiran (Riskesdas, 2013). Pengobatan tradisional merupakan pengobatan atau perawatan dengan berdasarkan kepada pengalaman, keterampilan turun temurun, pelatihan, dan diterapkan sesuai dengan norma yang berlaku dalam masyarakat (Glanzet al, 2008).

Pengobatan tradisional yang cukup populer di masyarakat Indonesia adalah pengobatan fraktur, atau sering disebut masyarakat sebagai dukun patah tulang. Tidak sedikit pasien fraktur sebelum datang ke Rumah Sakit, mereka terlebih dahulu datang ke pengobatan tradisional. Sehingga pada saat datang ke rumah sakit sudah mengalami komplikasi akibat penanganan pertamanya yang tidak baik atau tidak sesuai prinsip yang benar. Kondisi ini dapat menyebabkan terjadiya neglected fraktur. Dampak dari kondisi ini dapat memperpanjang hari rawat pasien di rumah sakit sehingga dapat menimbulkan masalah sosio ekonomi berupa peningkatan biaya perawatan.

Selain berdampak terhadap sosio ekonomi, dampak lainnya adalah kecemasan. Menurut Wong, Chan, \& Chair (2010) tindakan operasi dapat menimbulkan kecemasan terhadap pasien. Untuk mencegah terjadinya komplikasi pada pasien dengan kasus fraktur diperlukan pemahaman dan 
keterampilan khusus dari perawat. Sehingga pasien akan mendapatkan pelayanan professional dan memadai dalam rangka mencegah berbagai komplikasi baik secara fisik maupun psikologis. Peran perawat sebagai pemberi asuhan keperawatan dilaksanakan secara langsung dengan memberikan asuhan keperawatan kepada pasien dengan masalah gangguan muskuloskletal. Salah satunya adalah pasien dengan neglected fraktur shaft femur sinistra.

Studi kasus dilaksanakan mulai dari pengkajian awal hingga pasien pulang. Seiring dengan perkembangan ilmu dan teknologi di bidang kesehatan, pengetahuan masyarakat semakin meningkat dalam bidang kesehatan, hal ini menjadikan pasien dan keluarga menjadi kritis baik terhadap rumah sakit maupun bagi pemberi pelayanan kesehatan, sehingga ini menjadi tantangan bagi tenaga kesehatan khususnya perawat untuk meningkatkan mutu pelayanan keperawatan dengan cara perlunya ada terobosan-terobosan baru dalam meningkatkan mutu asuhan keperawatan.

Adapun upaya yang dapat dilakukan untuk meningkatkan kualitas asuhan keperawatan yaitu dengan meningkatkan kompetensi dan pengetahuan perawat, dengan demikian perawat dituntut untuk semakin mempelajari bidang ilmu yang terkait dengan pemberian asuhan keperawatan serta teori model keperawatan yang dapat diterapkan dalam pemberian asuhan keperawatan. Pendekatan model keperawatan yang dapat digunakan dalam praktik keperawatan salah satunya adalah Virginia Henderson tentang 14 Pemenuhan Kebutuhan Dasar Manusia yang bertujuan untuk memandirikan pasien baik dalam keadaan sehat maupun sakit. Penerapan pendekatan teori 
keperawatan ini akan terlihat dari kemajuan kondisi pasien, yang semula bergantung pada orang lain menjadi mandiri. Perawat dapat membantu pasien beralih dari kondisi tergantung (dependent) menjadi mandiri (independen).

Teori ini juga dapat digunakan pada pasien yang mengalami gangguan muskuloskeletal. Salah satu gangguan muskuloskelatal adalah Neglected Fracture Of Left Shaft Femur. Diharapkan perawat dapat melakukan asuhan keperawatan secara maksimal sehingga pasien dapat beralih dari kondisi tergantung (dependent) menjadi mandiri (independen) dengan kondisi yang dialaminya. 


\section{BAB I \\ ANATOMI DAN FISIOLOGI TULANG}

\section{A. Tulang}

Tulang adalah jaringan yang tersusun oleh sel dan matriks kolagen ekstraselular (kolagen tipe I). Derajat kelenturan dan elastisitas tulang dapat berubah apabila mendapat tekanan. Tubuh manusia tersusun atas 206 segmen tulang yang membetuk rangka atau skeletal. Adapun fungsi dari tulang rangka atau skeletal adalah sebagai berikut:

1) Support atau penopang: Tulang memiliki peran sebagai struktur rangka tubuh serta tempat melekatnya otot dan jaringan lunak lainnya.

2) Protection atau perlindungan: Tulang berfungsi melindungi organ bagian dalam dari injuri atau cedera akibat tekanan atau benturan. Misalnya skull atau tulang tengkorak kepala melindungi otak, ribs/tulang rusuk melindungi jantung dan paru-paru, kemudian tulang vertebra melindungi medulla spinalis.

3) Penyimpanan dan pengeluaran mineral: Tulang berfungsi sebagai tempat penyimpanan mineral terutama kalsium dan fosfor. Mineral tersebut berperan untuk mengeraskan dan menguatkan struktur tulang. Sekitar 99\% mineral tubuh disimpan dalam tulang, mineral ini penting bagi aktivitas sel di seluruh tubuh. Sesuai kebutuhan, tulang akan melepaskan mineral ke dalam darah untuk mempertahankan keseimbangan mineral (homeostasis). 
4) Produksi sel darah: Eritrosit, leukosit dan trombosit diproduksi dalam tulang tertentu di sumsum tulang merah. Sumsum tulang merah ini terdapat pada tulang pelvis, sternum, vertebra, humerus dan femur. Dengan bertambahnya usia, beberapa sumsum tulang merah berubah dari merah menjadi kuning.

5) Movement atau pergerakan: Sebagian besar dari otot melekat pada tulang, ketika otot berkontraksi maka otot akan menarik tulang untuk melakukan gerakan. Gerakan yang dihasilkan dapat berupa gerakan oleh ujung jari hingga gerakan perubahan pada posisi seluruh tubuh.

\section{B. Histologi Jaringan Tulang}

Struktur tulang pada tingkat mikroskopis mengandung matriks ekstraseluler sekitar 15\% air, 30\% serat kolagen, dan 55\% kristal garam mineral. Kalsium fosfat [Ca $\left.\left(\mathrm{PO}_{4}\right)_{2}\right]$ merupakan garam mineral yang paling banyak terdapat dalam struktur tulang. Garam mineral ini bergabung dengan garam mineral lain yaitu kalsium hidroksida [Ca $(\mathrm{OH})_{2}$ ], yang akan membentuk kristal

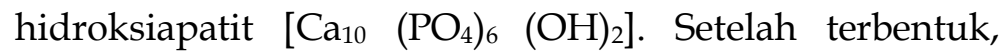
Kristal bergabung dengan kalsium karbonat $\left(\mathrm{C}_{\mathrm{a}} \mathrm{CO}_{3}\right)$, dan ion seperti kalium, magnesium, fluorida, dan sulfat. Setelah garam mineral tersimpan dalam tulang yang dibentuk oleh serat kolagen ekstraseluler matriks, garam mineral ini akan mengkristal dan mengeraskan jaringan tulang. Proses ini disebut kalsifikasi, yang dimulai oleh sel-sel pembentuk tulang yang disebut osteoblas. Terdapat empat jenis sel pada jaringan tulang yaitu :

1) Sel Osteogenik: Merupakan sel yang belum berdiferensiasi, berasal dari mesenkim. Sel osteogenik merupakan satu-satunya sel tulang yang mengalami 
pembelahan sel dan mempunyai kemampuan untuk berkembang menjadi osteoblast. Sel-sel osteogenik biasanya ditemukan pada bagian dalam periosteum, endosteum, dan kanal atau saluran tulang yang mengandung vaskular atau pembuluh darah.

2) Sel Osteoblast: Merupakan sel pembentuk tulang. Sel ini sintesis dan sekresi serat kolagen serta komponen organik lainnya yang diperlukan untuk membangun matriks ekstraselular tulang.

3) Sel Osteosit: Merupakan sel tulang matang yang berasal dari osteoblas.

4) Sel Osteoklast: Merupakan sel multinuclear besar berdiameter $100 \mu \mathrm{m}$ dengan 10-12 nukleus yang terdapat disepanjang permukaan tulang tempat terjadinya resorpsi, remodeling, dan perbaikan tulang. Osteoklas berasal dari precursor makrofag granulotik yang terdapat di dalam sumsum tulang yang masuk ke dalam peredaran darah sebagai monosit. Fungsi utamanya adalah meresorpsi tulang selama remodeling atau perbaikan tulang

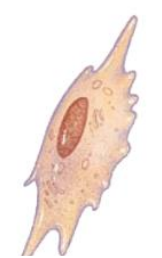

Sel

osteogenik berkembang menjadi osteoblast

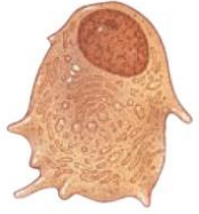

Osteoblast membentuk matriks ekstraselular tulang

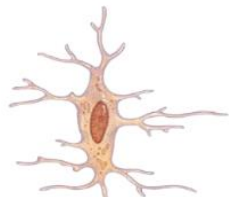

Osteoklast berfungsi resorpsi, pemecahan matriks ekstraselular tulang

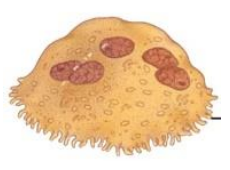

Osteosit mempertah ankan jaringan tulang

Gambar 1.1; Sel tulang (Tortora \& Derrickson, 2012) 
Tulang tidak sepenuhnya padat tetapi memiliki banyak ruang kecil di antara sel-sel dan komponen matriks ekstraseluler. Beberapa ruang berfungsi sebagai saluran untuk pembuluh darah yang mensuplai atau memasok nutrisi ke sel-sel tulang. Ruang lain sebagai area penyimpanan untuk sumsum tulang merah. Regio atau daerah tulang dikategorikan menjadi substansi compacta dan substansi spongiosa. Secara keseluruhan, 80\% kerangka tulang adalah substansi compacta dan 20\% substansi spongiosa.

\section{Substansi Tulang Kompak}

Memiliki beberapa ruang dan merupakan bentuk terkuat dari jaringan tulang. Substansi kompak ditemukan di bawah periosteum semua tulang dan sebagian besar membentuk tonjolan dari bagian diafisis tulang panjang. Jaringan tulang compacta memberikan perlindungan dan topangan serta menahan dari tekanan yang ditimbulkan oleh berat badan dan gerakan. Jaringan tulang compacta terdiri dari unit struktural berulang yang disebut osteon, atau sistem havers. Setiap osteon terdiri dari lamela konsentrik yang tersusun di sekitar kanalis sentralis (havers). Menyerupai cincin pertumbuhan pohon, lamela konsentrik adalah lempengan sirkular atau melingkar dari mineral matriks ekstraselular dengan penambahan diameter, yang mengelilingi pembuluh darah, limfatik, dan saraf yang terletak di kanalis sentralis. Unit-unit tulang ini seperti tabung umumnya membentuk rangkaian silinder yang sejajar, pada tulang panjang, cenderung sejajar dengan sumbu tulang panjang. Di antara lamella konsentrik terdapat ruang kecil yang disebut lakunae yang mengandung osteosit. Adapun yang menjalar ke semua arah dari lakuna adalah 
kanalikuli kecil (saluran kecil) yang terisi oleh cairan ekstraselular. Di dalam kanalikuli terdapat penonjolan osteosit. Osteosit berbatasan dihubungkan melalui gap junction. Kanalikuli menghubungkan lakuna satu dengan lainnya melalui kanalis sentralis yang membentuk sistem kanal miniature, berkelok-kelok yang saling berhubungan di seluruh tulang. Rangkaian ini memberi banyak jalur untuk nutrisi dan oksigen mencapai osteosit dan pembuangan sampah metabolisme.

\section{Substansi Tulang Spongiosa}

Berbeda dengan jaringan tulang kompak, substansi jaringan tulang spongiosa disebut sebagai jaringan tulang trabekular atau kanselosa, tidak mengandung atau berisi osteon. Jaringan tulang spongiosa selalu terletak di bagian dalam tulang, dilindungi oleh lapisan tulang compacta. Terdiri dari lamela yang tersusun dalam pola yang tidak beraturan yang disebut trabekula. Antara trabekula terdapat ruang-ruang. Ruang tersebut diisi oleh sumsum tulang merah dalam tulang yang menghasilkan sel-sel darah dan sumsum tulang kuning pada tulang lain. Kedua sumsum tulang mengandung banyak pembuluh darah kecil yang menyediakan nutrisi bagi osteosit. Setiap trabekula terdiri dari lamela konsentrik, yaitu osteosit terletak di lakuna, dan kanalikuli yang menyebar keluar dari lakunae.Jaringan tulang spongiosa membentuk sebagian besar jaringan tulang bagian dalam yaitu tulang pendek, tulang pipih, tulang sesamoid, dan tulang irregular. 


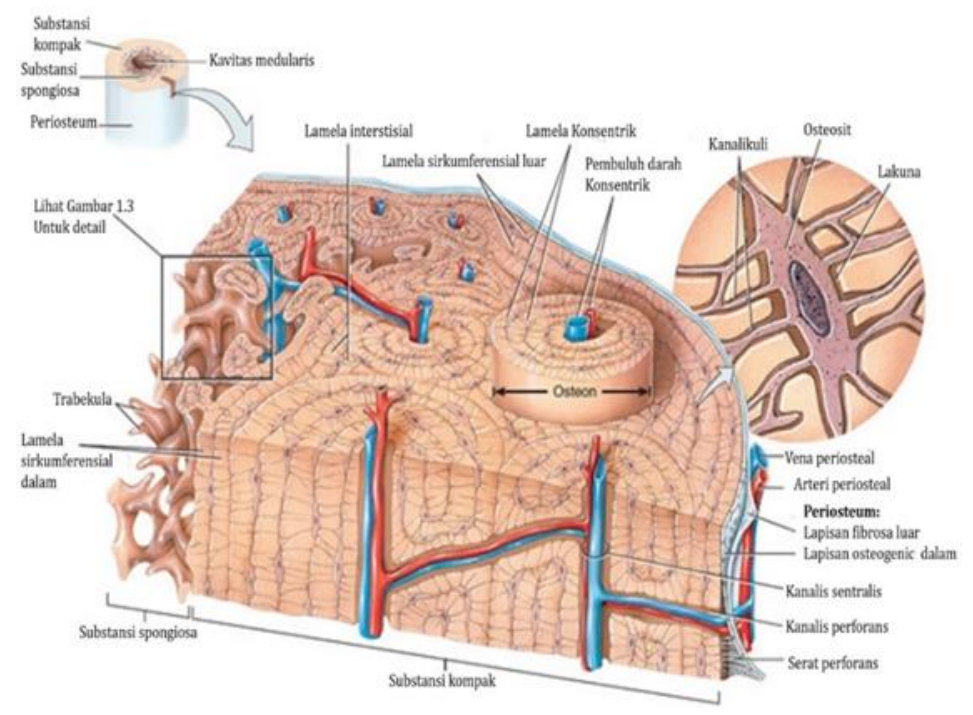

Gambar 1.2; Osteon (Tortora \& Derrickson, 2012)

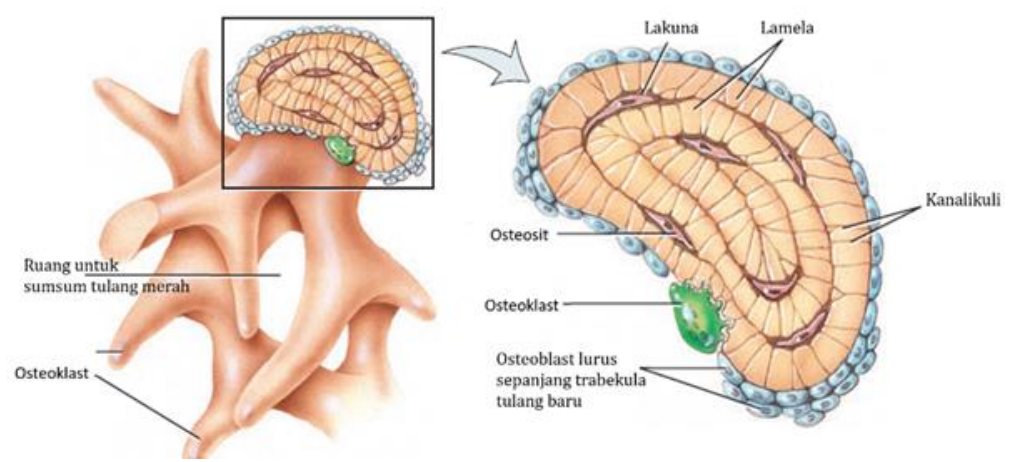

Gambar 1.3; Aspek trabekula substantia spongiosa. Potongan trabekula (Tortora \& Derrickson, 2012)

\section{E. Aliran Darah Dan Persarafan}

Tulang memiliki banyak pembuluh darah. Khususnya di bagian tulang yang mengandung sumsum tulang merah, masuk ke dalam tulang melalui lapisan periosteum. Arteri periosteal merupakan pembuluh darah kecil yang disertai dengan saraf. Pembulih darah tersebut masuk ke dalam tulang bagian diafisis atau batang tulang melalui Aplikasi Asuhan Keperawatan NEGLECTED FRACTURE OF LEFT SHAFT FEMUR 6 | dengan TEORI VIRGINIA HENDERSON 
banyak kanal atau saluran perforans (Volkmann) yang memperdarahi periosteum dan bagian luar substansi kompak. Dekat dengan pusat diafisis, terdapat arteri nutricia berjalan melalui lubang pada substansi kompak yang disebut foramen nutricia. Ketika memasuki rongga atau cavitas medulari, arteri nutricia terbagi menjadi cabang proksimal dan distal yang menuju ke setiap bagian ujung tulang. Cabang-cabang ini memperdarahi baik bagian dalam jaringan tulang kompak maupun spongiosa dan sumsum tulang merah sepanjang epifisis.

\section{F. Klasifikasi Tulang}

Berdasarkan bentuk dan ukurannya, tulang dapat diklasifikasikan sebagai berikut;

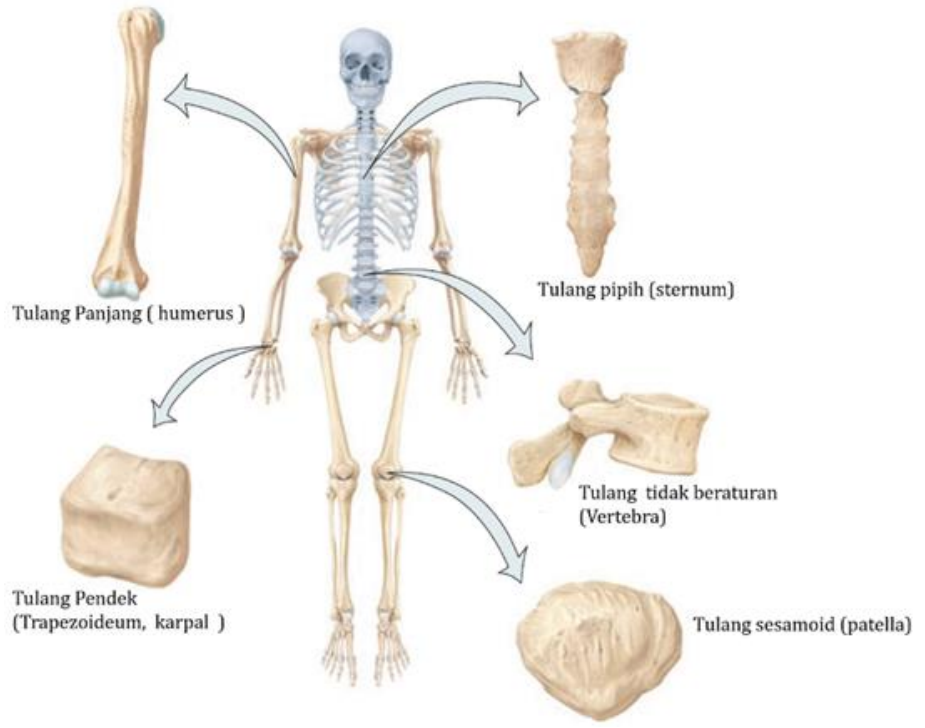

Gambar 1.4; Klasifikasi tulang (Tortora \& Derrickson, 2012)

\section{1) Tulang Panjang}

Tulang panjang berbentuk seperti pipa, kedua ujungnya bulat, sementara pada bagian tengahnya berbentuk silindris. Seluruh bagian tulang panjang 
tersusun dari substansi tulang kompak (tulang padat) dengan sedikit substansi atau komponen tulang spongiosa (tulang berongga-rongga). Pada bagian dalam tulang panjang terdapat rongga yang berisi sumsum tulang.Tulang panjang terbagi atas tiga bagian, yaitu bagian ujung disebut epifisis yang tersusun atas tulang rawan, sementara pada bagian tengah adalah diafisis/Shaft tersusun atas tulang keras. Bagian antara epifisis dan diafisis disebut metafisis yang terdiri atas tulang rawan dan mengandung banyak osteoblas. Bagian metafisis merupakan bagian yang dapat bertambah panjang terutama dalam usia masa pertumbuhan. Tulang panjang terdapat pada bagian tubuh yaitu femur, humerus, radius, ulna, tiba dan fibula.

\section{2) Tulang Pendek}

Tulang pendek diselubungi jaringan padat tipis. tulang ini bersifat ringan dan kuat serta memungkinkan untuk meredam goncangan yang keras. Tulang ini terdapat pada pergelangan tangan (wrists), pergelangan kaki (ankles) yaitu karpal dan tarsal.

\section{3) Tulang Pipih}

Berbentuk gepeng, tersusun atas dua lapisan subtansi kompak yaitu lamina eksterna dan interna. Tulang pipih terdapat pada tulang cranium, scapula, sternum. Tulang pipih berfungsi melindungi organ - organ inernal tubuh seperti otak, jantung, dan paru - paru. 


\section{4) Tulang Tidak Beraturan}

Merupakan tulang yang bentuknya tidak beraturan, terdapat pada vertebra. Fungsinya sebagai artikulasi dan melekatnya struktur lainnya (otot).

\section{5) Tulang Sesamoid}

Tulang yang terletak pada persendian berbentuk bulat terdapat pada sendi lutut yaitu patella. Tulang sesamoid berfungsi melindungi tendon dari tekanan dan regangan. 


\section{BAB II \\ KONSEP FRAKTUR SHAFT FEMUR DAN TEORI VIRGINIA HENDERSON}

\section{A. Fraktur Shaft Femur}

\section{1) Anatomi}

Shaft femur adalah bagian dari tulang panjang yang berada di regio $5 \mathrm{~cm}$ dari trokanter mayor dan berakhir $9 \mathrm{~cm}$ diatas sendi lutut. Secara anatomis dapat dilihat pada gambar 2.1 berikut ini.

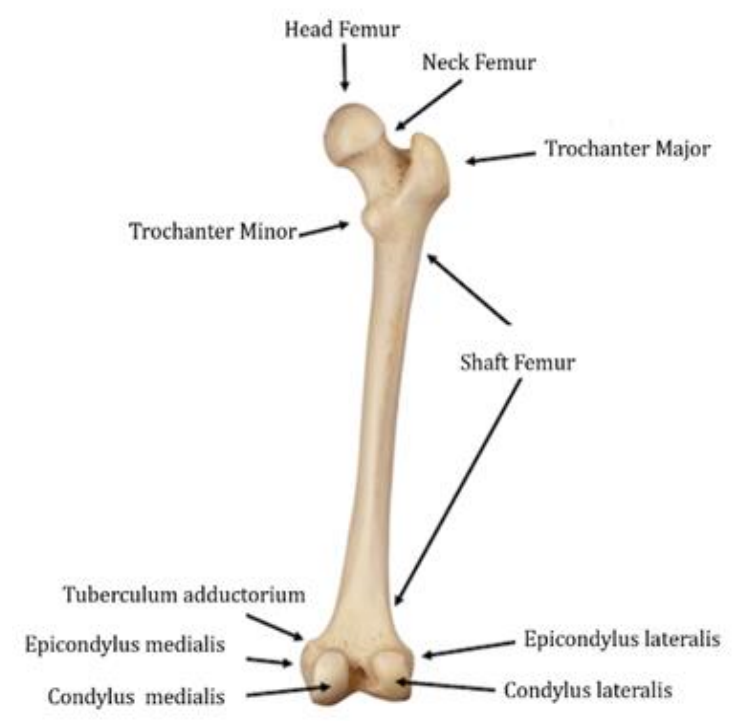

Gambar 2.1 Anatomi Shaft Femur (Tortora \& Derrickson, 2012)

\section{2) Pengertian}

Fraktur shaft femur merupakan diskontinuitas (fraktur) pada tulang femur yang mengenai bagian shaft atau diafise tulang femur masalah yang umumnya terjadi pada dewasa muda yang 
diakibatkan trauma langsung dengan kekuatan tinggi dan keras yang biasanya disebabkan oleh kecelakan lalu lintas, jatuh dari ketinggian dan luka tembak (OTA, 2011; Lewis et al, 2007).

\section{3) Etiologi}

Penyebab utama fraktur shaft femur adalah kecelakaan lalu lintas dan jatuh dari ketinggian (OTA, 2011) Penyebab lainnya adalah osteoporosis yang biasanya terjadi pada usia di atas 65 tahun (Orthopaedia, 2011).

\section{4) Klasifikasi}

Klasifikasi menurut Winquist and Hansen membagi fraktur shaft femur berdasarkan jumlah patahan yaitu :

- Tipe 0 merupakan fraktur shaft femur tanpa patahan atau kupu-kupu kecil kurang dari $25 \%$ tulang.

- Tipe I merupakan fraktur shaft femur dengan fragmen kupu-kupu $\leq 50 \%$ dari lebar tulang

- Tipe II merupakan fraktur shaft femur dengan fragmen kupu-kupu lebih dari 50\%

- Tipe III merupakan fraktur shaft femur yang berat dan mengenai seluruh segmen tulang

- Tipe IV merupakan fraktur shaft femur dengan kehilangan fragmen tulang 